\title{
Faktor Yang Berhubungan Dengan Penerimaan Keluarga Terhadap Anak Retardasi Mental Di Sekolah Luar Biasa-C YPPLB Pembina Makassar
}

\author{
Satriana Dardi ${ }^{1^{*}}$ \\ 1*. STIKPER Gunung Sari Makassar, Jl. Sultan Alauddin No.293, Kota Makassar, Indonesia, 90221 \\ *email : nhanatriyana87@gmail.com/081343958122
}

(Received : 15-03-2019; Reviewed : 23-03-2019; Accepted : 13-04-2019)

\begin{abstract}
The purpose of this study is to understand whether there was a correlation among knowledge, family'seconomic condition, and social support with the acceptance of family to mentally retarded children at extraordinary school-C Makassar's extraordinary education development foundation.The design in this study used a descriptive research design with a cross sectional study approach, namelly by collecting data at one time. The total population was 41 people. The results of this study using the SPSS Version 23 Chi-Square Test with $\alpha=0.05$. There was a correlation between knowledge and the acceptance of family to mentally retarded children because $p<\alpha, p=0.008$. There was correlation between family's economic condition and the acceptance of family tomentally retarded children because $p$ $<\alpha, p=0.008$. Also, Therewas a correlation between social support and the acceptance of family to children with mental retardation because $p<\alpha, p=0.014$.
\end{abstract}

Keywords : Economic Condition, Family Support, Knowledge, Social Support and Mental Retardation in Children

\begin{abstract}
Abstrak
Tujuan dalam penelitian ini adalah untuk mengetahui ada hubungan pengetahuan, ekonomi keluarga dan dukungan sosial dengan penerimaan keluarga terhadap anak retardasi mental di Sekolah Luar Biasa-C Yayasan Pembinaan Pendidikan Luar Biasa Makassar. Desain dalam penelitian ini menggunakan desain penelitian deskriptif dengan pendekatan Cross Sectional Study yaitu dengan cara mengumpulkan data sekaligus pada suatu waktu. Jumlah populasi sebanyak 41 orang. Pengambilan sampel dalam penelitian ini menggunakan tehnik Total sampling. Hasil penelitian ini menggunakan Uji statistik Uji Chi-Square SPSS Versi 23 dengan $\alpha=0,05$. Kesimpulan penelitian ini adalah ada hubungan pengetahuan dengan penerimaan keluarga pada anak retardasi mental karena $p<\alpha$ yaitu $p=0,008$. Ada hubungan ekonomi keluarga dengan penerimaan keluarga pada anak retardasi mental karena $p<\alpha$ yaitu $p=0,008$. Ada hubungan dukungan sosial dengan penerimaaan keluarga pada anak retardasi mental karena $\mathrm{p}<\alpha$ yaitu $\mathrm{p}=0,014$.
\end{abstract}

Kata Kunci : Dukungan Sosial, Ekonomi Keluarga, Pengetahuan dan Retardasi Mental Pada Anak 


\section{Pendahuluan}

Menurut World Health Organization (WHO) retardasi mental adalah kemampuan mental yang tidak mencukupi. Carter $\mathrm{CH}$ dikutip dari Toback Cretardasi mental adalah suatu kondisi yang di tandai oleh intelegensi yang rendah menyebabkan ketidak mampuan individu untuk belajar dan beradaptasi terhadap tuntutan masyarakat atas kemampuan yang dianggap normal. Menurut Crocker AC retardasi mental adalah terdapat fungsi intelegensi yang rendah, yang disertai adanya kendala dalam penyesuaian perilaku, dan gejalanya timbul pada masaper kembangan. (Soetjiningsih, 2012)

Menurut WHO jumlah anak berkebutuhan khusus di Indonesia adalah sekitar 7\% dari total jumlah anak usia 018 tahun atau sebesar 6.230.000 pada tahun 2007. Menurut data Sensus Biro Pusat Statistik, pada tahun 2009 jumlah penyandang cacat yang ada di sekolah sebesar 85.645 anak dengan rincian di SLB sebanyak 70.501 anak dan di sekolah inklusif sebanyak 15.144 anak. Pada Riskesdas 2010 dikumpulkan data kecacatan hanya pada ana kusia 24-59 bulan. Berdasarkan data tersebut, persentase ana kusia 24-59 bulan yang termasuk dalam kategori tunagrahita sebanyak $0,14 \%$ (Riskesdas, 2010)

MenurutMaramis (2008), penderita retardasi mental di Indonesia diperkirakan 1-3\%, yang terdapat di kota dan di desa, dikalangan atas dan rakyat jelata, dalam keluarga terpelajar dan keluarga kurang terdidik, baik dalam keluarga kaya maupun miskin. Retardasi mental banyak ditemukan pada anak yang berusia 5-6 tahun, dan puncaknya pada golongan remaja umur 15 tahun. Dan masalah dunia dengan implikasi yang benar terutama bagi negara berkembang. Di perkirakan angka kejadian retardasi mental beratsekitar 0,3\% dari seluruh populasi, dan hampir $3 \%$ mempunyai IQ di bawah 70. Sebagai sumber daya manusia tentunya mereka tidak bisa di manfaatkan, karena $0,1 \%$ dari anak-anak ini memerlukan perawatan, bimbingan serta pengawasan sepanjang hidupnya. (Soetjiningsih, 2012)

Berdasarkan pendataan hasil kerjasama Departemen Sosial RI dan surveyor Indonesia padatahun 2008, jumlah penyandang disabilitas sekitar 34.510 orang di Provinsi Sulawesi Selatan yang tersebar di 24 Kota/ Kabupaten. Sedangkan populasi penyandang disabilitas (difable) terdata di Kota Makassar sebanyak 2.250 orang yang terdiriatas 1.794 orang penyandang disabilitas fisik, 242 orang penyandang disabilitas mental dan 214 orang penyandang disabilitas fisik dan mental.

Retardasi Mental yaitu gangguan dalam perkembangan dimana terjadi gangguan dalam fungsi intelektual yang sub normal adanya perilaku adaptif social dan timbul pada masa perkembangan yaitu di bawah umur 18 tahun. Terjadi gangguan dalam fungsi intelektual subnormal disini adalah dilakukan tes psikologis dengan tesangkatarafkecerdasanintelingence Quotient (IQ) dimana anak akan mempunyai IQ dibawah 70, kemudian perilaku adaptif social pada anak dengan retardasi mental dapat dilihat dengan cara kemampuan anak dalam melakukan tugas kemamdirian atau menyesuaikan diri dengan lingkungan dan tugas perkembangan pada usianya belum optimal. Berdasarkan tingkatan dalam retardasi mental dapat di bagimenja diempat kelompok retardasi mental di antaranya: retardasi mental ringan dengan taraf IQ: 50-70, retardasi mental sedang dengan taraf IQ: 35-49, retardasi mental beratdengantaraf IQ: 20-34, retardasi mental sangat berat dengan taraf IQ: kurangdari 20. (A. Aziz AlimulHidayat, 2012)

Kebanyakan anak yang menderita retardasi mental iniberasal dari golongan social ekonomi rendah, akibat kurang stimulasi dari lingkunganya sehingga secara bertahap menurungkan IQ yang bersamaan dengan terjadinya maturasi. Demikian pula pada keadaan social ekonomi yang rendah dapat sebagai penyebab organic dari retardasi mental, misalnya keracunan logam berat yang subklinik dalam jangka waktu yang lama dapat mempengaruhi kemampuan kognitif, ternyata lebih banyak padaa nak-anak di kota dari golongan social ekonomi rendah. Infeksisitomegala virus juga lebih banyakte rdapat pada ibu-ibu dari golongan social ekonomi rendah. Demikian pula dengan kurang gizi, baik pada ibu hamil maupun pada anaknya setelah lahir dapat mempengaruhi pertumbuhan otak anak. (Soetjiningsih, 2012)

Banyak ahli setuju bahwa karakteristik orang dengan retardasi mental berkembang dicara yang sama seperti orang tanpa retardasi mental, tetapi pada tingkat yang lebih lambat. Lain-lain menunjukkan bahwa orang-orang dengan retardasi mental memiliki kesulitan dalam khusus bidang pemikiran dasar dan pembelajaran seperti perhatian, persepsi atau memori. Tergantung pada sejauh mana penurunan ringan, sedang, berat, atau mendalam, individu dengan retardasi mental akan mengembangkan berbeda dalam sosial, dan keterampilan kejuruan akademik.(Amy Gralfitrisia, 2012)

Karena penyembuhan dari retardasi mental ini boleh dikatakan tidak ada. Sebab kerusakan dari sel-sel otak tidak mungkin fungsinya dapat kembali normal, maka yang penting adalah pencegahan primer yaitu usaha yang dilakukan untuk mencegah terjadinya penyakit.Dengan memberikan perlindungan terhadap penyakit-penyakit yang potensial dapat mengakibatkan retardasi mental. Misalnya melalui imunisasi, konseling perkawinan, pemeriksaan kehamilan yang rutin, nutrisi yang baik selama kehamilan, dan bersalin pada tenaga kesehatan yang berwenang, maka dapat membantu menurunkan angka kejadian retardasi mental. Demikian pula dengan mengentaskan kemiskinan dengan membuka lapangan kerja, memberikan pendidikan yang baik, memperbaik isanitasi lingkungan, meningkatkan gizi keluarga, akan meningkatkan ketahanan terhadap penyakit. Denganadanya program BKB (Bina Keluarga dan Balita) yang merupakan stimulasi mental dini dan bisa dikembangkan juga deteksi dini, maka dapat mengoptimalkan perkembangan anak.(Soetjiningsih, 2012). 
Berdasarkan data yang di dapatpadatanggal 18 april 2018 di SLB-C YPPLB Makassar di dapatkan jumlah keseluruhan siswa sebanyak 64 siswa terdapat 41 orang yang mengalami retardasi mental diantaranya laki-laki sebanyak 28 orang dan perempuan sebanyak 13 orang. Berdasarkan dari data tersebutpeneliti ingin mengetahui apakah keluarga mampu menerima dengan baik anak yang mengalami retardasi mental. Sehingga penulis tertarik untuk meneliti Faktor Yang Berhubungan Dengan Penerimaan Keluarga Terhadap Anak Retardasi Mental Di SekolahLuar Biasa-C YPPLB Pembina Makassar.

\section{Metode}

Metode penelitian ini adalah Deskriptif kuantitatif dengan pendekatan Cross-Sektional Study yaitu menekankan waktu pengukuran dalam variabel independen dan dependen hanya satu kali pada satu saat. Dengan tujuan untuk mengetahui pengaruh pengetahuan, ekonomi keluarga, dan dukungan keluarga terhadap penerimaan keluarga dengan anak retardasi mental. Populasi merupakan seluruh subjek dengan karakteristiktertentuyang akan diteliti. Populasi dalam penelitian ini adalah semua anak yang mengalamiretardasi mental yang ada di SLB-C YPPLB Makassar sebanyak 41 anak

Analisa Data

Analisis univariat digunakan untuk menjabarkan secara deskriptif mengenai disrtibusi frekuensi dan proporsi masing-masing variabel yang diteliti, baik variabel bebas maupun variabel terikat.Bertujuan untuk menjelaskan atau mendeskripsikan karakteristik setiap variabel penelitian.

Analisis bivariat yang dilakukan terhadap dua variabel yang diduga berhubungan atau korelasi. Analisis ini digunakan untuk menguji hipotesis dengan menentukan hubungan variabel bebas dan terikat melalui Uji Statistik ChiSquare dengan tingkat bermakna $\alpha$ :0,05. Dengan menggunakan computer program Software product and Sevice Solution ( SPSS versi 23,0).

\section{Hasil Penelitian}

Penelitian ini dilaksanakan di Sekolah Luar Biasa-C Yayasan Pembinaan Pendidikan Luar Biasa Makassar tanggal 18 Juni 2018 - tanggal 18 Juli 2018sebanyak 41 responden. Berdasarkan hasil pengolahan data dari kuesioner yang didapatkan dari responden diperoleh hasil penelitian sebagai berikut :

\section{Tabel 1. Hubungan pengetahuan dengan penerimaan keluarga terhadap anak retardasi mental di SLB-C YPPLB Makassar 2018}

\begin{tabular}{|c|c|c|c|c|c|c|c|c|}
\hline \multirow{3}{*}{ Pengetahuan } & \multicolumn{4}{|c|}{ Retardasi Mental Pada Anak } & \multirow{2}{*}{\multicolumn{2}{|c|}{ Total }} & \multirow{3}{*}{\multicolumn{2}{|c|}{$\mathbf{a}$}} \\
\hline & \multicolumn{2}{|c|}{ Ringan } & \multicolumn{2}{|c|}{ Berat } & & & & \\
\hline & $\mathbf{n}$ & $\%$ & $\mathbf{n}$ & $\%$ & $\mathbf{n}$ & $\%$ & & \\
\hline Baik & 21 & 51,2 & 2 & 4,9 & 23 & 56,1 & & \\
\hline Kurang Baik & 10 & 24,4 & 8 & 19,5 & 18 & 43,9 & 0,008 & 0,05 \\
\hline Total & 31 & 75,6 & 10 & 24,4 & 41 & 100,0 & & \\
\hline
\end{tabular}

Dari tabel 1 menunjukan bahwa dari 41 responden yang memiliki hubungan pengetahuan baik terhadap anak yang mengalami retardasi mental ringan sebanyak $21(51,2 \%)$ orang dan reponden yang memiliki hubungan pengetahuan baik terhadap anak yang mengalami retardasi mental berat sebanyak $2(4,9 \%)$ orang. Sedangkan responden yang memiliki hubungan pengetahuan kurang baik terhadap anak yang mengalami retardasi mental ringan sebanyak 10 $(24,4 \%)$ orang dan reponden yang memiliki hubungan pengetahuan kurang baik terhadap anak yang mengalami retardasi mental berat sebanyak $8(19,5 \%)$ orang.

Berdasarkan hasil analisa data dengan menggunakan uji chi square pada variabel ini maka diperoleh nilai $=$ 0,008 lebih kecil dari tingkat kemaknaan yang ditentukan yaitu $=0,05$ dimana nilai $<\alpha$. Maka dapat diartikan bahwa Ha di terima dan H0 ditolak. Dengan demikian, dapat disimpulkan bahwa "Ada hubungan antara pengetahuan dengan penerimaan keluarga terhadap anak retardasi mental di SLB-C YPPLB Makassar”. 
Tabel 2. hubungan ekonomi keluarga dengan penerimaan keluarga terhadap anak retadasi mental di SLB-C YPPLB Makassar 2018

\begin{tabular}{|c|c|c|c|c|c|c|c|c|}
\hline \multirow{3}{*}{$\begin{array}{l}\text { Ekonomi } \\
\text { Keluarga }\end{array}$} & \multicolumn{4}{|c|}{ Retardasi Mental Pada Anak } & \multirow{2}{*}{\multicolumn{2}{|c|}{ Total }} & \multirow{3}{*}{\multicolumn{2}{|c|}{$\mathbf{a}$}} \\
\hline & \multicolumn{2}{|c|}{ Ringan } & \multicolumn{2}{|c|}{ Berat } & & & & \\
\hline & $\mathbf{n}$ & $\%$ & $\mathbf{n}$ & $\%$ & $\mathbf{n}$ & $\%$ & & \\
\hline Baik & 21 & 51,2 & 2 & 4,9 & 23 & 56,1 & & \\
\hline Kurang Baik & 10 & 24,4 & 8 & 19,5 & 18 & 43,9 & 0,008 & 0,05 \\
\hline Total & 31 & 75,6 & 10 & 24,4 & 41 & 100,0 & & \\
\hline
\end{tabular}

Dari tabel 2 menunjukkan bahwa dari 41 responden yang memiliki hubungan ekonomi keluarga baik terhadap anak yang mengalami retardasi mental ringan sebanyak $21(51,2 \%)$ orang dan reponden yang memiliki hubungan ekonomi keluarga baik terhadap anak yang mengalami retardasi mental berat sebanyak 2 (4,9\%) orang. Sedangkan responden yang memiliki hubungan ekonomi keluarga kurang baik terhadap anak yang mengalami retardasi mental ringan sebanyak $10(24,4 \%)$ orang dan reponden yang memiliki hubungan ekonomi keluarga kurang baik terhadap anak yang mengalami retardasi mental berat sebanyak 8 (19,5\%) orang.

Berdasarkan hasil analisa data dengan menggunakan uji chi square pada variabel ini maka diperoleh nilai = 0,008 lebih kecil dari tingkat kemaknaan yang ditentukan yaitu $=0,05$ dimana nilai $<\alpha$. Maka dapat diartikan bahwa Ha di terima dan H0 ditolak. Dengan demikian, dapat disimpulkan bahwa ada hubungan antara ekonomi keluarga dengan penerimaan keluarga terhadap anak retardasi mental di SLB-C YPPLB Makassar.

Tabel 3. hubungan dukungan sosial dengan penerimaan keluarga terhadap anak retardasimental di SLB-C YPPLB Makassar 2018

\begin{tabular}{|c|c|c|c|c|c|c|c|c|}
\hline \multirow{3}{*}{$\begin{array}{c}\text { Dukungan } \\
\text { Sosial }\end{array}$} & \multicolumn{4}{|c|}{ Retardasi Mental Pada Anak } & \multirow{2}{*}{\multicolumn{2}{|c|}{ Total }} & \multirow{3}{*}{\multicolumn{2}{|c|}{$\mathbf{a}$}} \\
\hline & \multicolumn{2}{|c|}{ Ringan } & \multicolumn{2}{|c|}{ Berat } & & & & \\
\hline & $\mathbf{n}$ & $\%$ & $\mathbf{n}$ & $\%$ & $\mathbf{n}$ & $\%$ & & \\
\hline Baik & 20 & 48,8 & 2 & 4,9 & 23 & 56,1 & & \\
\hline Kurang Baik & 11 & 26,8 & 8 & 19,5 & 18 & 43,9 & 0.014 & 0.05 \\
\hline Total & 31 & 75,6 & 10 & 24,4 & 41 & 100,0 & & \\
\hline
\end{tabular}

Dari tabel 3 menunjukkan bahwa dari 41 responden yang memiliki hubungan dukungan sosial baik terhadap anak yang mengalami retardasi mental ringan sebanyak20 $(48,8 \%)$ orang dan responden yang memiliki hubungan dukungan sosial baik terhadap anak yang mengalami retardasi mental berat sebanyak 2 (4,9\%) orang. Sedangkan responden yang memiliki hubungan dukungan sosial kurangterhadap anak yang mengalami retardasi mental ringan sebanyak11 (26,8\%) orang dan reponden yang memiliki hubungan dukungan sosial kurang terhadap anak yang mengalami retardasi mental berat sebanyak 8 (19,5\%)orang.

Berdasarkan hasil analisa data dengan menggunakan uji chi square pada variabel ini maka diperoleh nilai = 0,014 lebih kecil dari tingkat kemaknaan yang ditentukan yaitu $=0,05$ dimana nilai $<\alpha$ maka dapat diartikan bahwa Ha di terima dan H0 ditolak. Sehingga disimpulkan ada hubungan antara dukungan sosial dengan penerimaan keluarga terhadap anak retardasi mental di SLB-C YPPLB Makassar.

\section{Pembahasan}

1. Hubungan Pengetahuan dengan Penerimaan Keluarga Terhadap Anak Retardasi Mental Di SLB-C YPPLB Makassar

Dari hasil penelitian menunjukan bahwa tingkat pengetahuan keluarga tentang penerimaan anak retardasi mental di Sekolah Luar Biasa-C Yayasan Pembinaan Pendidikan Luar Biasa Makassar dalam keadaan yang baik. Dengan pengetahuan yang baik terhadap anak retardasi mental tersebut sudah seharusnya keluarga mengetahui cara mendidik dan mengasuh anaknya dengan retardasi mental tersebut. Dengan pengetahuan yang baik akan membantu keluarga memaksimalkan usahanya dalam memberikan yang terbaik untuk anak-anaknya yang memiliki kebutuhan khusus dibandingkan anak normal lainnya.

Pengetahuan keluarga yang baik akan mempengaruhi penerimaan mereka terhadap anaknya, dengan pengetahuan yang lebih terhadap penanganan anak dengan retardasi mental akan membantu keluarga khususnya ibu dalam memberikan pengasuhan kepada anaknya sehingga anaknya dapat tumbuh dan kembang dengan maksimal dan dapat memperoleh kebutuhannya dari keluarga dan lingkungan. Dengan pengetahuan yang baik dari keluarga akan mempengaruhi perlakuan keluarga kepada anak dengan retardasi mental agar tidak selalu dibeda-bedakan dengan anak normal lainnya atau dengan kata lain tidak mengucilkan anak dengan retardasi mental yang dialaminya. 
2. Hubungan Ekonomi Keluarga dengan Penerimaan Keluarga Terhadap Anak Retardasi Mental Di SLB-C YPPLB Makassar

Berdasarkan dari hasil penelitian yang dilakukan oleh peneliti, diperoleh hasil penelitian bahwa ada hubungan ekonomi keluarga dengan penerimaan keluarga terhadap anak dengan retardasi mental di Sekolah Luar Biasa-C Yayasan Pembinaan Pendidikan Luar Biasa Makassar. Dengan ekonomi keluarga dalam kategori yang baik ( keluarga yang mampu dalam finansial ) menyebabkan penerimaan keluarga terhadap anak dengan retardasi mental akan baik diwujudkan dengan keluarga memberikan yang terbaik kepada anaknya untuk perkembangan anaknya yang lebih baik. Dengan keuangan keluarga yang lebih akan menjadikan keluarga selalu memberikan pengobatan kepada anaknya agar bisa mendapatkan perubahan kesehatan kearah yang lebih baik dan memenuhi semua kebutuhan anaknya dengan baik. Dan tidak terlalu mempermasalahkan anaknya dengan kedaanya yang retardasi mental. Berbeda dengan keluarga yang kurang mampu (ekonimi yang kurang ) anak dengan retardasi mental cenderung menjadi beban dalam keluarga sehingga sering dikucilkan oleh anggota keluarga lainnya. Dapat pula peneliti menyimpulkan bahwa ekonomi keluarga yang kurang akan mempengaruhi penerimaan keluarga terhadap anak retardasi mental karena keluarga menganggap anak tersebut menjadi beban dalam keluarga karena begitu banyak kebutuhan yang harus dipenuhinya untuk kebutuhan anak retardasi mental tersebut sehingga sering kali keluarga kurang memberikan respon yang baik terhadap anaknya dengan kebutuhan khusus dengan retardasi mental tersebut.

3. Hubungan Dukungan Sosial dengan Penerimaan Keluarga Terhadap Anak Retardasi Mental Di SLB-C YPPLB Makassar

Dari hasil penelitian yang dilakukan oleh peneliti, peneliti dapat menyimpulkan bahwa ada hubungan dukungan sosial terhadap penerimaan keluarga terhadap anak dengan retardasi mental di Sekolah Luar Biasa-C Yayasan Pembinaan Pendidikan Luar Biasa Makassar. Dengan dukungan sosial yang baik dari masyarakat sekitar akan mempengaruhi penerimaan keluarga terhadap anaknya. Tidak dikucilkan dalam masyarakat akan sangat berdampak bagi penerimaan keluarga terhadap anaknya. Dengankata lain dukungan sosial sangat berpengaruh terhadap penerimaan anak dengan retardasi mental. Sebaliknya jika dalam lingkungan sosial anak retardasi mental di perlakukan dengan tidak baik maka berpengaruh terhadap perlakuan keluarga kepadanya.Dukungan sosial sangat berpengaruh terhadap penerimaan keluarga terhadap anak retardasi mental oleh sebab itu anak dengan retardasi mental harus diperlakukan baik dalam kehidupan masyarakat jangan sebaliknya menyudutkan dan mengucilkannya. Dengan dukungan sosial yang fositif terhadap keluarga dengan anak retardasi mental akan mempengaruhi pola pengasuhan keluarga kepada anaknya tersebut. Keluarga akan memperlakukan anaknya dengan baik kerna mendapatkan pula dukungan yang foditif dari lingkungan sosila disekitarnya. Aura yang fositif dari lingkungan sosial akan berdampak fositif terhadap perlakuan keluarga kepada anak dengan retardasi mental.

\section{Kesimpulan}

Kesimpulan dari penelitian ini adalah ada hubungan pengetahuan ( $\mathrm{P}: 0,08)$, ekonomi keluarga $(\mathrm{P}: 0,08)$, dan dukungan sosial $(\mathrm{P}: 0,014)$ terhadap penerimaan keluarga dengan anak retardasi mental di Sekolah Luar Biasa-C Yayasan Pembinaan Pedidikan Luar Biasa Makassar.

\section{Saran}

Kepada Keluarga khususnya ibu yang dalam keluarga memiliki anak dengan retardasi mental agar memperlakukan anaknya sesuai dengan kebutuhan tumbuh kembangnya. Dan kepada khalayak banyak dalam masyarakat jika menemukan keluarga atau ibu dengan anak retardasi mental diharapkan jangan mengucilkan atau menyudutkan dalam kehidupan sosial karena itu sangat berpengaruh terhadap penerimaan keluarga khususnya ibu terhadap anaknya tersebut. Yang berpengaruh terhadap pengasuhan anaknya dalam keluarganya.

\section{Referensi}

A A Hidayat (2011). Metode Penelitian Keperawatan dan Teknik AnalisaData.Jakarta :salemba medika

A A Hidayat (2012). Pengantar Ilmu Keperawatan Anak. Jakarta: Salemba Medika.

Bandiyah Siti. (2011). Psikologi Kesehatan. Yogyakarta: Nuha Medika.

B B Septiari.(2012).Mencetak Balita Cerdas dan Pola Asuh Orang Tua. Yogyakarta: Nuha Medika.

D S Cahyaningsih.(2011). Pertumbuhan Perkembangan Anak dan Remaja. Jakarta: Trans Info Media. 
D S H Putra. (2014). Keperawatan Anak \& Tumbuh Kembang(Pengkajian Dan Pengukuran). Yogyakarta: Nuha Medika.

Dosenekonomi (n.d).Diakses pada tanggal 23 Juli 2018. Darihttps://dosenekonomi.com/ilmu-ekonomi/ekonomimikro/fungsi-ekonomi-dalam-keluarga

G Amy.(2012).Dukungan Keluarga Dalam Merawat Anak RetardasiMental. Sumatera Utara: Fakultas Keperawatan.

H Adnani.(2011). Ilmu Kesehatan Masyarakat. Yogyakarta: Nuha Medika.

Maya \& Fida.(2012). Pengantar Ilmu Kesehatan Anak. Yogyakarta: D Medika

R Agus.(2011). Aplikasi Metode Penelitian Kesehatan. Yogyakarta: NuhaMedika

Soetjiningsih.(2012).Tumbuh Kembang Anak. Jakarta: Buku Kedokteran EGC

Setiadi.(2008). Konsep Dan Proses Keperawatan Keluarga. Yogyakarta: Graha Ilmu.

Suyanto.(2011). Metodologi Dan Aplikasi Penelitian Keperawatan. Yogyakarta:Nuha Medika

R S Sukarmin.(2009). Asuhan Keperawatan Pada Anak. Yogyakarta:Graha Ilmu

Y Supartini. (2014). Buku Ajar Konsep Dasar Keperawatan Anak. Jakarta:EGC. 